\title{
Third Party Funding in International Arbitration in Iran
}

Financiamiento de terceros en arbitraje internacional en Irán

Mahsa Molavi*

Islamic Azad University - Iran mahsa.molavi@yahoo.com

\begin{abstract}
The present research focuses on arbitration, which seeks to examine the advantages and disadvantages of third party funding(TPF) and its differences with other forms of financial interference and determines who can act as an investor. The result of this research is that third party funding has disadvantages and advantages that in general, its advantages are dominated due to the difference in volume of funding, and investors in this area can be lawyers, insurance companies or any other person who is not prohibited by law and can be simulated and executed under the Article 10 of civil law.
\end{abstract}

Keywords: Third Party Fundings, International Arbitration, Differences, Independence of the Referee, Costs of Proceedings

\section{RESUMEN}

La presente investigación se centra en el arbitraje, que busca examinar las ventajas y desventajas del financiamiento de terceros (TPF) y sus diferencias con otras formas de interferencia financiera y determina quién puede actuar como inversionista. El resultado de esta investigación es que la financiación de terceros tiene desventajas y ventajas que, en general, sus ventajas están dominadas debido a la diferencia en el volumen de financiación, y los inversores en esta área pueden ser abogados, compañías de seguros o cualquier otra persona que no esté prohibida. por ley y puede simularse y ejecutarse de conformidad con el artículo 10 del derecho civil.

Palabras clave: financiación de terceros, arbitraje internacional, diferencias, independencia del árbitro, costos de los procedimientos

* Master student, Islamic Azad University, Science and Research Branch, Tehran, Iran

Recibido: 21/05/2019 Aceptado: 19/09/2019 
Introduction

One of the issues that are considered for discussion is the cost to individuals. There has always been a view that the cost and timing of arbitration are less than costs of proceedings and judicial services, but this depends on the legal system of the host country, the complexity of the case and the possibility of resorting to existing jurisdictional competence. Access to justice is one of the fundamental rights around the world that has come into existence with various tools and methods to achieve this, which, of course, are not always efficient, but its advantage is sharing a global concern (Endicott, 2012), which leads to better solutions. When one of the arbitration agreement parties cannot afford the costs of arbitration, it practically deprives the right of access to justice because it does not find the opportunity to express his claims. In order to access to justice, it is vital that right holders in a judicial or quasi-judicial process can obtain the right by legal means. Here, the issue of TPF in arbitration arises and its significance is determined. It is crystal clear that in international commercial litigation, that generally the amount claimed cash is significant, if the loser party due to incapability to judge in arbitration courts, cannot claim and recover his lost rights, he will suffer of great losses. From the author's opinion, third party funding in the arbitration is a positive step towards the implementation of justice. Compared to legal litigation, the issue of a third party's funding in international arbitration is one of the new issues in the international arbitration field.

The precise definition of TPF is ambiguous, and its legal and moral exemplifications in international arbitration remained mostly unchecked (Pinna, 2010). However, definitions have been provided regarding this term, including third party funding, in particular, is a financing method that includes non-refundable funding in litigation or arbitration, which, in return, provides a share of the profits by specialized suppliers (with good faith) that are neither parties to the dispute nor closely related to the dispute and whose sole benefit is monetary (Cremades, 2011). However, who are the specialized suppliers, there is much debate that will be addressed in this article.

Many countries have accepted this legal innovation and implemented it in their legal system. Australia and England have significant experience in the TPF market. Australia was the first country to create a TPF market in arbitration and litigations (Cremades, 2013). Today, third party funding is spreading around the global. The Hong Kong Law Reform Commission has recently conducted a deep study on third party funding in arbitration, organized by a committee of experts. The committee suggested that such a reformation would be possible under domestic law. However, they stated that financial and ethical standards would be developed for this purpose (Boulle). Singapore also endorsed the adoption of its bill on the amendment of its civil law dated January 10, 2017, by abolishing the common law of quasi-crime about champerty of TPF. The framework established by law in the regulations (third party funding) was described at the appendix of the civil law. As it can be seen, countries are constantly adopting such a phenomenon and try to apply it in their own laws (CAG, 2006), which we will discuss in more detail. In addition, the International Council for Commercial Arbitration has created a special TPF team in partnership with the University of Queen Mary, London. However, third party funding in arbitration also has damages and challenges, since in fact the third party investor is not a party to the arbitration and has not a position but is beneficiary due to the funding. This can be the reason for his undue involvement in the course of the arbitration. Therefore, third party funding is in fact a two-edged knife that should be used with caution.

On the other hand, some countries prohibit third party funding in arbitration. In some systems, TPF may be considered as usury. Some legal systems also know conditional contracts illegal. However, what is certain is that the domestic laws of the countries will adapt about the various aspects of such a phenomenon, since the existence of such a phenomenon can help the realization of justice, if it is within the framework of financial and moral standards. Hence, Iran, as a funding country, needs such an important acceptance in order to ensure investors and foreign companies to achieve their rights. Apart from explicit prohibitions on some legal systems, TPF contracts may also be subject to interferences. In some jurisdictions, TPF contracts can be regulated in accordance with the definition of regulatory financial regulation. In some US states, the after the event-TPF construction is considered as a non-refundable loan (Garcia, 2018). In the Netherlands, a TPF contract between the professional parties informed of the potential risks and benefits is certainly supported by a legal court. In terms of litigation delivery to third parties, the French law is relatively complex and not regulated. Although it seems to be no guidance in judicial proceedings, French law prohibits the litigation delivery related to damages. In addition, in order to preserve the trust of society in the functioning of this system, Article 1597 of the civil law prohibits the acquisition of specific claims by individuals involved in the legal system (Barker). In Germany's law, there is little market for commercial TPF, and it is expected that market grow in the near future. Investors are usually involved in commercial litigation, part of the befor the event- LEI competition market (widely used in the German consumer market) (Cremades, 2013). In England and Wales, the principles of common law against maintenance, and champerty (as well as lawsuit) are the main obstacles to the creation of a market for litigation. Under common law, maintenance means intrusive intervention that in any way does not belong to the prosecutor or helps to any of the parties through money or other means. This assistance in prosecuting or defending litigation is by a person who has no good faith in the matter or involves interference with another person's litigation. Champerty, which is a kind of maintenance, involves support (financial or other means) from litigation and lawsuit refers to litigation stimulation. The prohibition of champerty agreements is essentially a lawsuit-investing ban. This prohibits the financial support of another person's litigation for a share in the proceeds. If a contract violates the prohibition of maintenance and champerty, then that contract is considered invalid. Third party funding in Hong Kong is in the early stages of its development compared to other countries with common laws like Britain and the United States. This is mainly used to invest in insolvency cases since funding in such cases has been permitted in Hong Kong since 2010.

In this paper, the author attempts to study the various dimensions of TPF in arbitration considering the actions of various countries, and the its capability to apply in domestic laws of Iran, according to what has been posted so far, and 
that the subject of this research is completely novel. One of the challenges of this research, which we will discuss in the article, is who can be involved as a third party in investing in arbitration. To sum up, we are attempting to study this innovation from the viewpoint of international law and the rules governing international arbitration, and to study its domestic dimensions applicability. The purpose of the new laws and regulations has always been to protect the interests of individuals, and since third party funding can help to protect individuals' rights and access to justice. On the other hand, because this is a new and emerging phenomenon and lack of research in this field is obvious in our country, its importance becomes serious. The lack of such research leads to the fact that this legal innovation in our country has not taken into consideration and, consequently, no action has taken to examine its feasibility in domestic laws and ultimately its implementation. Therefore, the purpose of this study is to examine the TPF in international arbitration and, accordingly, these assumptions are introduced (Endicott, 2012) the third party funding in international commercial arbitration is effective on the performance of arbitration and at the same time, it can cause delay and miuse and can be effective in domestic law for better access to justice. (Pinna, 2010) All natural and legal persons with the required qualifications and competence may participate as third party investors in arbitration cases unless otherwise provided by law (Cremades, 2011) Third party funding in international commercial arbitration can be effective in adjudicating their rights; and (Cremades, 2013) Third party funding in international commercial arbitration may has arbitration proceedings face with challenge of delay and misuse.

\section{Research Methodology}

The method of this paper is descriptive-analytic. This paper is collected using library tools and based on the description and analysis of the contents related to the subject from foreign books and articles. After studying the intended sections, considering the organization of the paper and the initial plan, notes were taken and then in each section, these notes have been used in the topics covered by referencing the exact source. About collecting information, it has been effort to obtain context from authoritative sources.

\section{findings}

Legal implications of third party funding

In the field of arbitration, third party funding is a specialized type of financing of a dispute in which a third party provides arbitration costs to one of the parties of the dispute. Instead, the investor requests a degree of control over the case and receives a percentage of the loss determined in the event of success. If the dispute fails, the investor will not receive any damages and will pay the legal expenses of the claimant team as well as other mutual costs. The volume of litigation and arbitration costs is very high, and often exceeds hundreds of millions of dollars. This leads to attracting investors and, therefore, has its own legal effects, which, a brief description of each one is described below.

- The effect of TPF in the refereeing process: If presence of a third party funding plan is not disclosed to the court at the beginning, an arbitrator may not know that he is in a conflict of interest position (Cremades, 2007). The potential consequences of a conflict of interest between an arbitrator and a third party investor of a party may disrupt the overall arbitration process. Beyond the concerns about the legitimacy and integrity of arbitration tribunals, there is a need for an information disclosure regime that is also stimulated by third party funding agreements through concerns about effectiveness. A definitely worse scenario is that after final verdict is issued, revocation trials are based on the absence of an arbitrator's independence or impartiality due to a conflict of interest with a third party investor. Revocation translates to time and loss of significant sources that can be prevented by mandatory disclosing the third party funding measures.

- Independence of arbitrator and conflict of interests: Contrary to the principle of neutrality, which refers to the absence of a deviation and illegal mental bias of an arbitrator towards one party or issue of a dispute, independence refers to the arbitrator's relations with other parties or actors involved in a dispute, which is assessed based on an objective basis and requires that an arbitrator discloses any conflicts of interest with the parties or with third party investors. The principles of the independence and impartiality of judges also include the absence of appearances of dependency or bias. The principles of independence and impartiality are provided in the rules of the main arbitration institutions. Articles 11 and 12 of the United Nations Commission for International Trade Rules of Arbitration Laws (UNCITRAL) provide for the independence and impartiality of the arbitrators and their respective duty to disclose the circumstances, which may lead to a challenge to these principles. Article 14 (Endicott, 2012) of the International Convention on the Settlement of Funding Disputes (ICSID) requires that arbitrators have a high degree of moral integrity and be able to be independent in their judgment and Article 57 of the ICSID Convention, expresses the ineligibility of an arbitrator on the basis of any fact, of the apparent lack of qualifications required by paragraph 1 of Article 14 .

\section{Ethical Concerns and Legal Challenges}

Discussion on ethical issues in common law countries focuses more on ethical rules of professional counseling than on the application of maintenance and champerty doctrines for TPF relationships. Among these cases, it appears that these jurisdiction fields are free of old doctrines of maintenance and champerty, and of the possible constraints of their TPF measures. Here are some of the key issues in this area. 
- Third Party funding: Maintenance is an aid in prosecuting or defending a legal case granted to a claimant by a person who has no benefit and interest in the good faith in the lawsuit, that is, the intervention in another person's lawsuit. The champerty is an agreement between an intrusive interventionist in a lawsuit and a claimant, whereby the intervener helps to pursue the claimant and, in return, receives a portion of the amount paid. (Jern-Fei Ng, 2010) In a simple word, in USSC, maintenance helps someone else to prosecute for a lawsuit; champerty is keeping a lawsuit for a financial benefit at the end, and disputing is continues of maintenance or champerty activity. According to the definition, these doctrines prevent TPF. However, in practice, as shown later, the restrictions imposed by these doctrines are often moderated or abandoned. Theoretically, some jurisdictions of the common law still consider the intervention of a third party to be inaccurate. However, in practice, these rigorous ethical regulations have been significantly moderated in many jurisdictions and have been completely abolished in some jurisdictions. However, champerty has not yet gone away. The courts can still abandon the TPF's agreement on the basis that they are of a kind of champerty one, and therefore are contrary to public policy. In addition, some interpreters and organizations such as the US Chamber of Institute for Legal Reform (ILF) purposes reviewing the previous ban on Anglo-Saxon champerty law. Ultimately, these doctrines can be considered as a pre-existing legal framework for TPF, which has made redundant the more regulations in this area. However, these doctrines are older than the TPF industry and therefore are not ideal frameworks, especially considering the contrast between their forms and their application across different jurisdictions, and the lack of relevance to modern business transactions.

- Third party funding and usury: Laws of usury prohibit high interest rates and in relation to its historical significance, is similar to the champerty doctrine. The obvious question that arises here is whether the TPF agreements can be considered as a loan with regard to the utility of usury. In the first place, it seems that the rules of usury consider most of the funding agreements to be illegal. It is not yet clear whether all TPF agreements can be considered as loans or not. In relation to the United States, the law in most states considers fundings in TPF agreements, not their loans, because of their conditional nature. Therefore, investors are not subject to the legal restrictions imposed on interest rates by the laws of usury. However, the local ban on usury can, under certain conditions, still affect the validity of funding agreements if the investor seeks for a high rate of return and a successful lawsuit, because usury agreements are against public policy, and for this reason, one can abolish them.

- National limitations in international arbitration: The purpose of several doctrines is essentially to prevent certain procedures in the area of litigation. This raises the question of whether these doctrines are applied in the private arbitration world. It is likely that the remaining restrictions or prohibitions imposed by these doctrines will not load any burden on arbitration disputes due to the inappropriateness of the general political protection of the internal civil justice system, the system which is the basis of the prohibition of legal proceedings of the courts. In the private arbitration world, the parties' demands are mainly dominant and prominent (Kantor, 2009). There are numerous probabilities in which these doctrines can play an important role in international arbitration. First, the parties and the tribunal must obey the local mandatory laws that judgment takes place. Secondly, a court can, in executive procedures, impose its opinion on the validity of TPF agreements or decide that the TPF agreement is in conflict with public policy. One can also imagine a situation in which a claimant investor guarantees payment or satisfaction vote and subsequently no longer has a great desire to divide the amount agreed upon with the investor. In such cases, the funding client is trying to get a ruling from the local court to reject the funding agreement, which releases the invested party from its obligations. The author agrees with Rodgers' view that the champerty and the related doctrines are not types of public policy, because they targeted the parties for funding agreements, not for the ethical result of which they invested. However, many interpreters still suggest that the implementation of votes can be rejected for reasons of public policy, in spite of the fact that there is no general public in which identification and execution are actually due to the fact that an investor Is involved in trials, has been rejected (Rodak, 2006).

\section{Moral duties of lawyer}

The topics discussed in this section are of a more theoretical nature, because the local ethical rules are generally not applicable to the consultation of the parties in international arbitration. However, it seems that some investors do not want to accept that none of the ethical rules will be applied and therefore still act cautiously, for example, when transferring legal documents from or to lawyers. There are regulations to illustrate this issue that includes, confidentiality, the interests of the lawyer's ethical duties, the duty of knowing and the duty of informing a lawyer about third party funding.

\section{Advantages of Third Party funding}

Access to Justice: The importance of third party funding in facilitating access to justice is widely accepted in many jurisdictions around the world. The right holders in arbitration cases that have limited financial resources can use third party funding to pursue and resolve their claims. An increase in third party funding has coincided with a significant decline in public funding in civil matters in countries such as Britain and Australia. The British Revolutionary Court's decision in Arkin's case against Borchard Lang is considered a milestone in recognizing British courts that third party funding can provide access to justice. In Australia, the main and fundamental decision of the court regarding third party funding is the decision of the Australian Supreme Court on Campbell Cash and Carrie Petty LTD against Fastiue LTD (Scherer, 2013)

- Risk management and financial support: Third party funding not only provides financial resources, but it can also be followed up by a lawsuit, as well as providing opportunities for managing financial risks along with pursuing a 
lawsuit through arbitration. A claimant can transfer some or all of these risks to the investor. The claimant will has the opportunity to obtain a successful compensation without the need to pay legal fees and other expenses incurred during the pursuit of the claim, or without the need to provide or allocate funds to deal with the consequences if the lawsuit failed (Max Bonnell, 2008). Controlling arbitration costs is one of the most worrisome issues in the arbitration community (McLachlan, 2007). The ability to distribute and share these risks with a third party may be appealing even for clients with strong business and financial flows.

- Verification: Before the agreement on the funding on a lawsuit, much extensive verification activities will usually be carried out by the investor. Some investors will carry out verification with external consultants at the expense of the client or themselves. Most verifiers invest mostly internally, relying on the skills and experience of their funding staff. An investor carefully and thoroughly analyzes and evaluates all aspects of the claim that he/she wants to accept its financial risks and analyzes and evaluates all aspects of a lawsuit that he or she has been asked to divide or control his financial risks. These factors include the prospect of litigation success, possible controversial lawsuits, the conditions of the arbitration agreement or treaty, the arbitration institution and the composition of the arbitral tribunal (if specified), the place of arbitration, the material rights of the dispute, the amount of the claim in comparison with the costs and its probable pursuing risks and the risks associated with executing and obtaining a payment under a single vote (including, for international commercial arbitrations), this question, which is a valuable asset in a government that is a signatory to the New York Convention.

-Experience: An experienced investor will be able to help the lawyer and claimant during the period of verification and arbitration, for example, in selecting advisers, experts, arbitrators and in appropriate cases related to the jurisdiction, in strategic and tactical decisions during the judgment. Given a wide range of specialized and experienced skills and consistent with their own business goals, an investor can add value to the management and resolution of arbitration cases. Usually, the investor will agree to hire the lawyer of claimant. Sometimes the claimant understands that his lawyer does not have the necessary skills and experience to conduct the arbitration and seeks help from the investor to get a more appropriate lawyer. Always, the lawyer who works for the claimant will remain the lawyer and will exclusively have duties and responsibilities to the claimant. The lawyer will probably be required to submit regular reports to the investor to monitor the progress of the lawsuit and ensure compliance with the obligations of the claimant under the funding agreement (especially in cases where there is compensation).

\section{Disadvantages of Third Party Funding}

Certain specific risks are unavoidable in third party funding in commercial arbitration and international treaties. Many of these risks originate from significant amounts of money that should be spent on the arbitration process and significant amounts that likely to be cast in the vote. Claimants and their lawyers must fully understand these risks so that claimants can make consciously and informed decisions regarding the use of TPF. The main risks associated with the ways in which most of these risks are addressed are described below.

- Unfair conditions: By providing funding, investors may find economies of scale in relation to the willingness of the investor to obtain the result of the dispute. Equally, more-endangered investors are dependent on continued cooperation and goodwill to advance bilateral efforts. In the field of litigation funding and in the case of small or unskilled claimant, the balance of economic power between the investor and the claimant has been one of the concerns of legislators (Choharis, 1995). It is a concern that an investor can, by insisting on unfair conditions in a funding agreement and using his economic position to renegotiate a situation against the claimant, at the final stage of the litigation process or in resolving a lawsuit in a way that is not compatible with the best interests of the client, it provides poor conditions. A claimant and investor may have a great deal of autonomy in designing a funding agreement and choosing the law governing a funding agreement, but since funding is not constantly regulated, this also means that the claimants enjoy low regulatory support (Pitkowitz, 2018)

- Investor's financial resources: An investor agreement to pay legal expenses of claimant and any harmful expense order may be misleading if the investor lacks sufficient capital or insurance to meet his obligations. It is important that the assets and capital structure of the investor be well understood by one of his claimants and advisers, and then it is easy to imagine the investor's ability to fulfill all the obligations that may occur under a funding agreement. Therefore, claimants must fully examine the investor's funding position and the transparency of his business structure before entering into a funding agreement. When seeking funding, their claimants and their lawyers must perform a precise validation about investors who want to invest in their claims, both because of the investor's financial position and record of backgrounds and in terms of the experience and competence of his employees.

Conflicts of Interests: The lawyer of claimant may be unreasonably affected by the investor (because the investor pays bills) and, in this case, is more in favor of the interests of the investor than the interests of the claimant. Lawyers should carefully review any relationship that maybe with an investor and ensure that all necessary information is disclosed to a client so that the client can make conscious decisions about the funding issue and the risks and benefits (Radek, 2016). This can be difficult and hard in the area of negotiation to resolve disputes, especially in situations where the investor and the claimant may have a disagreement to settle a lawsuit.

- Confidentiality and issues of special rights: The duty of a lawyer to be confidential with regard to a client seeking 
funding may be compromised by providing information related to lawsuit to the investor. Usually, a confidentiality agreement will be signed between the investor and the claimant at first, or the confidentiality regulations will be inserted in the funding agreement. However, depending on any jurisdiction, the contractual rules of confidentiality may not prohibit a reader to access documents that are available to the investor if they are related to the issues (Review of Civil Litigation Costs, 2009). In addition, there is a risk that special legal right contained in the documents provided by the claimant lawyer or in the event of disputes, in cases where the other special right relationship is given to the investor, be ignored or that the relationship between the investor and the invested claimant or the claimant's lawyer for a special right claim in jurisdictions that do not recognize the special right of mutual interest does not protect. These restrictions will reduce third party funding in these jurisdictions, and if full benefits of the TPF are available, it may ultimately require the decisive authority of the court or the legislator's intervention (Appelbaum, 2005).

Disclosure of Funding and Costs: In relation to the investor and his client, the issue of disclosure of the funding agreement to third parties is fundamentally related to the agreement between them. However, a wider question arises as to whether or not the claimant is committed to inform an investor's participation in a lawsuit or a judgment. It seems that there are no relevant rules in any prominent arbitration institutions that force one party to disclose the investor. However, this information may be disclosed by the investor during the arbitration. Claimant may wish to voluntarily disclose the use of the funding, and the investor may, under any circumstances, or during verification, be informed of the funding during the arbitration period or when negotiating to resolve the dispute.

- Investors regulation: Unlike lawyers whose activity is regulated by the local community or the legal community, there is little external control over the activity of a third party investor, except where this may be due to the location of the investor company; (for example, if the investor is listed on a stock exchange) or where the investor enters into funding measures (for example, funding measures may be regulated products by law). There is currently no comprehensive global legal regime for monitoring third party investors in international commercial arbitration or treaty litigation. Given that arbitration tribunals usually do not have the power to issue judgments against third parties, the limited ability to regulate investor activity in an international context can create real problems with the arbitration. Likewise, arbitration firms have no specific rules that require a party to disclose a funding contract, so arbitrators may not even be aware of an investor's involvement. As stated above, a statutory analysis needs to analyze the rules of each relevant legal regime at the place of arbitration. Such as the National Financial Services Regulations (Perry, 2018).

\section{Law applicable to TPF}

When examining Private International Law (PIL) issues, we must distinguish between different relationships and identifying the applicable law:

- Law Applicable to the Nature of the Funding Dispute (law governing claims): Funding treaty, the law applicable to the contract itself (to the extent that it relates to funding arbitration).

- The law governing claims may also specify whether and to what extent claims for damages can be transferred to third parties.

Applicable law on arbitration agreement between Investor and host government: Funding treaty or law applicable to arbitration clause

Law applicable to arbitration itself (law governing arbitration): ICSID treaty or arbitration law of arbitration law (means the national legal system through a statutory clause)

-The law applicable to the TPF contract between the claimant and the TPF investor

-The law applicable to the legal services contract between the claimant and the legal adviser/lawyer who is lawyer of the case. Considering that, each of these rules is applicable to the ethics of the Bar Association governing the exclusive right of the client-lawyer).

- Law applicable to the ethics of professional counseling established by the Bar Association of which he is a member.

Entering into a TPF contract with a choice-of-law clause (and a sub-court selection clause) and the associated legal system - such as German or Dutch law - as substantive rights applicable in the world of international arbitration would be better and relatively easy. However, one cannot argue that a court that is definitely opposed to the TPF's participation considers such a contract to be contrary to mandatory rules.

Funding Alternative Products: Flexible contractual arrangements governing funding of third party are of high value and are structured to suit specific parties, realities, and jurisdictions involved in litigation. The authors understand that there are no products or funding measures specifically designed for an international treaty or commercial arbitrations [28]. Treaty claims have unique procedural features and create additional procedural barriers. None of the main institutional rules contains explicit law regarding funding measures. Therefore, the funding options available in international arbitrations are depended on the location of the parties, the law of the location of arbitration and other relevant laws, and the creativity of claimants and their advisors. 
Lawyers in the United States often work in a consensual manner. This is not only common in lawsuits, but it also occurs in many forms in international commercial and treaty arbitration. Under a contractual fee arrangement, the lawyer will receive a percentage of each financial vote as part or all of the legal services he provides, and if there is no return, the lawyer will not receive any fees. Usually, since lawyers often risk significant professional fees, these measures are only taken by lawyers when a lawsuit is sufficiently well documented and a sufficient and appropriate return to compensate for non-payment risk to a lawyer be considered to enter into these agreements. Consensual measures between a lawyer and a claimant can allow the claimant to share the risk of paying lawyer fees.

Conditional Fee Agreements (CFAs) are a type of conditional fee agreements that are permitted in the UK and have become a common form of funding for civil lawsuit in this field. Although the agreement does not appear to be very broad, some English consultants work in arbitration under conditional measures. A CFA is an agreement between a law firm and a client stating that legal fees and costs or any portion of them will be paid in certain circumstances only if the client wins the proceedings. In these circumstances, the lawyer will receive his usual remuneration plus a successful remuneration. At present, the fee for success in England can be obtained from the loser.

In addition to the products described above that include lawyers and insurers, non-credit swaps of financial institutions may enable a claimant to reduce the inherent risks of arbitration proceedings.

- TPF Procedure: We do not know much about TPF procedures in commercial litigation. Commercial TPF investors operate in small markets with relative independence. They do not advertise extensively for their funding opportunities. However, it is clear that TPF is a comprehensive funding product and is not a contract for legal services. The TPF investor usually proposes to pay all costs imposed in a lawsuit against an agreed premium that is only payable in case of success. Successful premium can be paid in installments (for example $20 \%$ on the settlement before a hearing, $30 \%$ on court success up to $€ 500,000,20 \%$ on amounts over $€ 500,000)$. TPF investors prefer high-risk commercial litigation in such areas as patent litigation, antitrust litigation, and international arbitration. There are risks include losing that case, ordering to pay your own costs and the costs of the other party, and difficulties in implementing and receiving the lawsuit. Measures may vary depending on whether these risks are shared or how the risk is transferred to the TPF investor. The risk associated with high returns in winning cases is claimed to be $30 \%$ to $50 \%$.

\section{Possibility of third party funding in arbitration in Iranian law}

Disputes over funding contracts in countries such as Iran have always been largely due to existing political interactions. In fact, someday there may be a dispute between the parties to the contract and if the party who has lost his or her rights has suffered damage, due to the inability of supplying arbitration costs, it is barred from access to justice. Throughout the Constitution of the Islamic Republic of Iran, values such as justice, equality have been protected. Therefore, Article 9 of the Third Principle, in which the duties of the State are explained, a very essential duty has been considered: "The abolition of unjust discrimination and the creation of fair opportunities for all, in all material and Spiritual areas." In Article 14 of the same principle is also written: "It is the duty of the state to ensure the full enjoyment of the rights of men and women and to ensure the just litigation security for all and equality of the public before the law."

Principle 34 of the law states: "Litigation is an indispensable right of every person and any person may refer to the competent courts for justice for litigation. All the people of the nation have the right to have such courts available, and no one can be banned from a court that has the right to access it under the law." Constitution, which is the guider of the parliament in legislation area, has unequivocally recognized access to justice for all and emphasizes that this should be taken into serious consideration. Therefore, as a legislative pillar in the country, parliament can address this important issue, given the need for the country to be legally along with international law and other leading countries. On the other hand, the Article 10 of civil law expresses that: private contracts are permitted to the parties unless is not in explicit opposition against law. This article expresses the freedom of contracts and in fact, respects the decision of parties. Perhaps, there may be a question of its similarity with the champerty or similar institutions that have been addressed in previous discussions. Therefore, it is possible to consider such an institution in Iranian law and TPF in international commercial arbitration can be utilized under the article 10 of civil law. Hence, it is possible to design such entity in Iranian laws.

\section{Discussion and conclusion}

The growing phenomenon of TPF in international funding arbitration raises legal and ethical concerns that are largely unregulated by the core rules of arbitration entities. Given the high deterrent cost of international funding arbitration, the TPF allows a certain level of smoothing in playing field between the parties to a dispute. In some cases, foreign funding may enable investors with insufficient financial resources to initiate lawsuits against host governments and evaluate their claims based on their pros and cons.

However, by introducing another actor in this dispute, third party funding may have a destructive or even disruptive impact on the arbitration process. The purpose of this thesis is to examine the issues raised regarding third party funding in international funding arbitration and to highlight the need for an information disclosure regime to maintain the impartiality and independence of the arbitrators. 
In recent years, participants in this industry have been considering increasing interest and demand for third party funding in both litigation and arbitration. This increase is largely due to the increased costs associated with pursuing high-value litigation (especially lawyer and specialist fees) in many organizations that still feel the effects of the global crisis and the need to manage their financial risks carefully related to following up on significant litigation and in some jurisdictions, third party funding for many years has been a feature of the legal landscape. Investing in litigation is one of the institutionalized parts of the justice system in countries such as Australia and other common law countries such as Britain, Canada, and South Africa.

Third party funding refers to the tension between the limited jurisdiction competency of funding courts to resolve disputes between parties and to guarantee the effectiveness and integrity of international arbitration proceedings. Third party funding introduces another actor to international funding arbitration proceedings and thus increases the likelihood of conflict of interest between third party investors and arbitrators. Transparency through disclosure can act as a guarantee of independence and impartiality in funding arbitration proceedings and eliminate some of the legal and ethical concerns stated above. In international public law, international funding arbitration is structured differently from commercial arbitration. This type of funding requires a higher threshold of transparency, by disclosing the existence and (at least) the identity of third party investors due to the public interest involved in funding arbitration proceedings that governments are the parties.

The formal or explicit rules or regulations that are disclosed by third parties invested by third parties are currently insufficient to address this emerging phenomenon. However, nonobligatory votes, decrees, laws and instructions, and recent guidelines that provide the best practices indicate for greater transparency at the international level. These developments reveal a gradual change in the regulatory framework for third party funding, which is likely to help increase the effectiveness and integrity of international funding courts.

Although there are numerous funding options available for international treaty and commercial litigation, the advantages and financial risks associated with litigation suggest that they will likely provide attractive opportunities for future third party investors, and therefore they will be a valuable source for the claimants. The challenge is to ensure that resources of claimants and investors remain in the right balance and reflect the contrast between risks and benefits. Third party funding is neither a panacea nor a pest. Rather, for proper litigation, this approach can provide significant commercial benefits to claimants, and its evolution in the field of international treaty and commercial arbitration should be fostered rather than restricted. In Iranian law, it is possible to resort to third party funding in international litigation and it can be simulated and executed under Article 10 of the Civil law.

\section{BIBLIOGRAPHIC REFERENCES}

Appelbaum, Richmond B. (2011). "Lobby Battle Over Loans for Lawsuits," NY Times March 9.

Barker, George R. Third-Party Litigation Funding in Australia and Europe, 8 J.L. ECON. \& POL'Y 451-452.

Boulle, Thibault De. Third-party funding in international commercial arbitration, Master's thesis, FACULTY OF LAW GHENT UNIVERSITY, p. 40.

CAG. (2006). "Litigation Funding in Australia" Discussion Paper Standing Committee of Attorneys-General, May 2006

Choharis, Peter Charles. (1995). A Comprehensive Market Strategy For Tort Reform. 12 Yale J. on Reg. , p. 435525.

Cremades, Bernardo M. (2011). 'Third Party Litigation Funding: Investing in Arbitration', Transnational Dispute Management, 8:4.

Cremades, Bernardo M., and Dimolitsa, A. (2013). Third-party Funding in International Arbitration, International Chamber of Commerce (ICC), p.5.

Endicott, A., Giraldo-Carrillo, N., and J. Kalicki. (2012). "Third-Party Funding in Arbitration: Innovation and Limits in Self-Regulation (Part 1 of 2)", Kluwer Arbitration Blog 13 March.

Garcia, Frank J. (2018). Third-Party Funding as Exploitation of the Investment Treaty System, Boston College Law Review, Forthcoming 59, no.1. p. 5.

ICC. (2007) Techniques for Controlling Time and Costs in Arbitration, International Court of Arbitration Bulletin, a report from the ICC Commission on Arbitration, Volume 18, No. 1.

Jern-Fei Ng (2010). "The Role of the Doctrines of Champerty and Maintenance in Arbitration", 76(2) Arbitration 2010, 208-213;

Kantor, M. (2009). Third-Party Funding in International Arbitration: An essay about New Developments ICSID Review - Foreign Investment Law Journal, Volume 24, Number 1 (Spring) pp.70-71

Martin, S. (2004). "The Litigation Financing Industry: The Wild West of Finance Should Be Tamed Not

Outlawed”, 10 Fordham J. Corp. \& Fin. L. 2004, 58.

Max Bonnell, et al. (2008). 'Case notes on third-party funding', 3 Global Arbitration Review pp.35-37. 
McLachlan et al. 2007, p. 60 ff.; Tweeddale and Tweeddale 2005, p. 179 ff. Cf. Murray et al. 2007, p. 496;

Perry, Ronen. (2018.) Crowdfunding Civil Justice, 59 B.C.L.REV.1357,1365

Pinna, Andrea. (2010). "Financing civil litigation: the case for the assignment and securitization of liability claims", in: M. Tuil and L. Visscher (ed.), New Trends In Financing Civil Litigation In Europe - A Legal, Empirical, and Economic Analysis, Cheltenham/Northampton: Edward Elgar, p. 109-130

Pitkowitz, Nikolas,(2018) Handbook on Third-Party Funding in International Arbitration, Juris p. 260.

Radek Goral, (2016) The Law of Interest Versus the Interest of Law, or on Lending to Law Firms, 29 GEO. J. LEGAL ETHICS pp. 253, 303

Review of Civil Litigation Costs: Final Report, December 2009. P. 117;

Rodak, M. (2006) "It's about Time: A System Thinking Analysis of the Litigation Finance Industry and Its Effect on Settlement”, U. Pa. L. Rev., 512.

Rubin, P. (2011). “Third-Party Financing of Litigation”, 38(4) N. Ky. L. Rev. pp. 674-685

Scherer, M. (2013) "Third-party Funding in International Arbitration: Towards Mandatory Disclosure of Funding Agreements?” in B. CREMADES and A. DIMOLITSA (eds.), Dossier X: Third-party Funding in International Arbitration, Paris, ICC Publishing S.A,p. 95

The Article 42 of the UNCITRAL Arbitration Rules 2010 and Article 28(4) of the London Court of International Arbitration Rules.

The Law Reform Commission of Hong Kong, Consultation Paper, Third Party Funding for Arbitration, http:// www .hkreform.gov .hk/en/docs/tpf_e.pdf

Willem H. van Boom. (2011) Third party. Financing in International Investment Arbitration', Rotterdam Erasmus School of Law, p.25 